\title{
Neutralizing the Regulatory Burden: The Use of Equity Securities by Foreign Corporate Acquirers
}

Over the last ten years, foreign direct investment in the United States has increased dramatically. ${ }^{1}$ A substantial component of this trend has been the acquisition of domestic corporations by firms from a small group of highly developed countries. ${ }^{2}$ Although acquisitions can be structured in a variety of ways, foreign acquirers, unlike their

1. Foreign direct investment increased from $\$ 11.8$ billion in 1969 to $\$ 40.8$ billion in 1978, an increase of over 254\%. Devlin, The International Investment Position of the United Stales: Developments in 1970, Survey CuRrent Bus., Oct. 1971, at 21; Scholl, The International Investment Position of the United States: Developments in 1978, SuRveY Current Bus., Aug. 1979, at 56. "Foreign direct investment" is defined as a holding of greater than $10 \%$ of the voting securities of an incorporated business enterprise or an equivalent interest in an unincorporated enterprise by foreign persons. U.S. Dep't of Commerce News, Aug. 23, 1979 (Indus. \& Trade Admin. No. 79-138). Foreign portfolio investment, such as the passive holding of small amounts of stock, corporate bonds, and United States government obligations, is the residual of private foreign investment in the United States. $I d$.

Foreign direct investment comprises about $23 \%$ of all private foreign investment in the United States. See Scholl, supra, at 56. For a discussion of some of the factors explaining this increase, see Note, The Rising Tide of Reverse Flow: Would a Legislative Breakwater Violate U.S. Treaty Commitments? 72 MICH. L. Rev. 551, 552.53 (1974) [hereinafter cited as Rising Tide]; Note, Foreign Direct Investment in the United States: Possible Restrictions at Home and a New Climate for American Investment Abroad, 26 AM. L. REv. 109, 114-15 (1976).

2. I U.S. Dep't of Commerce, Foreign Direct Investment in the United States 115 (1976) (from 1970 to $1975,58 \%$ of sampled foreign direct investment was acquisitions) [hereinafter cited as ForEIGN DIRECT INvestment]. The volume of foreign acquisitions has not declined. See U.S. Dep't of Commerce News, Aug. 23, 1979 (Indus. \& Trade Admin. No. 79-138) (preliminary 1978 figures report 261 acquisitions, mergers and equity increases). Acquiring firms come predominantly from the United Kingdom, Canada, Federal Republic of Germany, Japan, France, Switzerland, and the Netherlands. Id. This Note defines a "foreign acquirer" as a business enterprise, domiciled in a nation belonging to the Organisation for Economic Co-operation and Development (OECD), that seeks to gain control of an American corporation. The condition of OECD affiliation guarantees that the business enterprise is subject to a certain and increasing level of domestic regulation. The OECD has recommended standards for minimum disclosure rules. OECD, Minimum Disclosure Rules Applicable to All Publicly Offered Securities (1976). All countries named above, except Switzerland, belong to the International Accounting Standards Committee, which publishes accounting standards enforceable by disciplinary proceedings. British Accountant Sees Progress in Setting International Standards, SEC. REG. \& L. REP. (BNA), Jan. 29, 1975, at A-17. In addition, the European Economic Community (EEC), of which many of these countries are members, has made significant progress in establishing minimum disclosure requirements for listed companies, Proposed Sixth Council Directive, reprinted in [1978] CoMm. MKr. REP. (CCH) I 1405, and standardizing accounting practices, Fourth Council Directive 78/660/EEC, 21 O.J. EUR. Comm. (No. L 222) 11 (1978), [1978] CoMM. MKr. ReP. (CCH) I 1391. 
domestic counterparts, use cash as consideration in virtually all acquisitions. ${ }^{3}$

This Note contends that the existing regulatory framework is a determinant of the acquisition form. ${ }^{4}$ Certain tax and securities regulations ${ }^{5}$ add costs to foreigners' securities acquisition transactions that domestic acquirers do not have to bear, steering foreign acquirers toward acquisitions structured as cash transactions. This regulatory effect contradicts stated United States policy on foreign investment and international capital movements. The Note therefore advocates adoption of a "standard of regulative neutrality" between foreign and domestic acquirers. The Note establishes a "criterion of effective parity" to implement this standard and uses that criterion to propose modifications in the existing regulatory framework.

\section{Acquisition Structuring and the Regulatory Impact on Foreign Acquirers}

The choice of a particular transaction structure, based upon the acquirer's evaluation of the structure's costs and advantages, affects the viability and efficiency of the transaction. ${ }^{6}$ Regulations that impose higher costs on foreign securities acquisitions, as compared to those of

3. I FOREIGN Direct InVESTMENT, supra note 2, at 116 (only four of forty-one acquisitions sampled used voting securities; three of these were pre-1970). This Note refers to acquisitions using equity securities as consideration as "securities acquisitions." The only post1970 securities acquisition, that of Alloys Unlimited, Inc. by Plessey Co. Ltd., occurred in 1971. Goldberg, Tax Considerations in Structuring the Acquisition of a U.S. Corporation, in Current Legal Aspects of Foreign Investuient in the United States 145, 145 (D. Evans, J. Forry, V. Narcisi, \& M. Perlberger eds. 1976). In the domestic context, however, securities acquisitions are showing signs of becoming more frequent. See Wall St. J., Dec. 5, 1979, at 1, col. 6 (report on letter by Federal Reserve Board Chairman Volcker). The SEC has been recciving an increasing number of requests from foreign parties for information on such acquisitions. Interview with Ronald Adee, Office of International Corporate Finance, SEC Division of Corporate Finance, in Washington, D.C., Nov. 13, 1979 (notes on file with Yale Law Journal).

4. Economic conditions can also make cash a desirable form of consideration for foreign acquirers. These conditions include a favorable exchange rate, large dollar surpluses from the chronic United States current account deficit, and "undervalued" U.S. assets and stock that make the tax benefits to the acquired's shareholders less attractive. See note 18 infra.

5. I.R.C. $\$ 367$; Securities Act of 1933, 15 U.S.C. $\$ \$ 77 \mathrm{a}-77 \mathrm{~mm}$ (1976 \& Supp. 1977) [hereinafter cited as Securities Act].

6. Many commentators assume that a decision to acquire has been made and that structuring is merely a technical choice of the best method. See, e.g., Nathan, Securities and Related Legal Factors in Planning a U.S. Acquisition by a Foreign Purchaser, in Foreign Investment in the United States 25, 28 (2d ed. J. Marans, P. Williams, \& A. Mirabito eds. 1978); Young, The Acquisition of United States Businesses by Foreign Investors, 30 Bus. LAw. 111, 115 (1974). It may be, however, that the ability to structure an acquisition satisfactorily actually determines whether or not the acquisition can be consummated. See J. Freund, Anatomy of a Merger 120 (1975). The structuring decision has important consequences for the essential terms of the transaction. See id.; 5 Foreign Direct INVESTMENT, supra note 2, at $\mathrm{H}-31$. 
domestic acquirers, can severely restrict the range of structuring options available to foreign acquirers.

\section{A. Structuring the Acquisition}

United States tax and securities regulations provide the framework of structuring options for an acquisition transaction. ${ }^{7}$ The basic regulatory distinctions depend upon the types of consideration used-cash, debt instruments, or equity securities. In cases in which debt or equity securities are used,$^{8}$ the securities rules distinguish between transactions in which stock of the acquired corporation is bought ${ }^{9}$ and those in which the assets are purchased or the acquired corporation is merged with the acquirer. ${ }^{10}$ The type of consideration determines the level of disclosure required. In addition, in acquisitions involving equity securities, the tax statutes also contain a classification system. Under section 368 of the Internal Revenue Code transactions that fall into any of the following three categories will be eligible for tax-free treatment: ${ }^{11}$

7. Schmults, Forms of Transactions, in MERgers ANd Acquisitions 54, 54 (J. McCord ed. 1969). Tax and securities regulations control the structuring of a transaction; they do not specifically prohibit transactions. See Elmer \& Johnson, Legal Obstacles to Foreign Acquisitions of U.S. Corporations, 30 Bus. LAw. 681, 684 (1975) (regulations do not directly prohibit foreign acquisitions).

The paradigm of structuring options that follows in the text is a formal one. Although most acquisition transactions will involve some added twists or even combinations of forms, such as two-step transactions, the possibilities presented in this Note are simplified in order to highlight the legal issues.

8. The use of securities in an acquisition transaction constitutes a public offering under section 5 of the Securities Act. See Nathan, supra note 6, at 43. Rule 146, 17 C.F.R. $\S 230.146$ (1979), and the statutory exemptions to section $5, \S \S 3($ a)(10)-(11), 4(2), are available to foreign acquirers seeking to conduct securities acquisitions.

9. The exchange offer is a type of tender offer in which the acquired's shareholders exchange their shares for shares of the acquirer. Nathan, supra note 6, at 39. The acquirer's shares must be registered on Form S-1. See Borden, Federal Securities Laws, in Business Acquisitions: Planning and Practice 5 (J.'Herz \& C. Baller eds. 1971) (Supp. 1973). If the issuer satisfies a number of conditions including being registered pursuant to section 12(b) of the Securities Exchange Act of 1934, 15 U.S.C. $\$ 78 l(b)$ (1976) [hereinafter cited as Exchange Act], and having filed all required reports under sections 13, 14, or 15(d) for a period of at least 36 months, it may use Form S-7. 17 C.F.R. $\$ 239.26$ (a)-.26(b) (1979) Thus, when an acquisition is a foreign acquirer's first dealing with the United States securities market, a Form S-1 registration is required.

10. Assets and merger transactions fall under the requirements of Rule 145, 17 C.F.R. $\$ 230.145$ (1979). Registration of a public offering under Rule 145 allows the use of Form S-14. Borden, supra note 9, at 24-26. In essence, Form S-14 consists of a merger proxy statement. Corporations already obligated to comply with Regulation 14A, 17 C.F.R. $\$ 240.14 a$ (1979), because of prior registration under the Exchange Act or Securities Act, will incur little additional expense in filing Form S-14. See Borden, supra note 9, at 25.

I1. See I.R.C. $\$ 368(a)(1)$ (defining transactions that will be "reorganizations" for purposes of $\$ \S 301-367)$. I.R.C. $\$ 368(a)(2)(D)$ provides for subsidiary mergers in which the acquired is merged into a subsidiary of the acquiring corporation. I.R.C. $\$ 368(a)(2)(E)$ provides for reverse subsidiary mergers in which a subsidiary of the acquiring corporation is merged into the acquired corporation. In both cases, the acquired corporation receives the stock of the parent corporation. 
mergers (type-A), ${ }^{12}$ stock for stock exchanges (type-B), ${ }^{13}$ and sales of assets (type-C). ${ }^{14}$

An acquirer thus faces a variety of structuring possibilities, each with distinct costs and benefits. Several factors are relevant to the choice among these options: financial considerations, such as the most desirable type of consideration, ${ }^{15}$ tax consequences, ${ }^{10}$ the continued participation of the acquired corporation's shareholders, ${ }^{17}$ and the likelihood of shareholder approval. ${ }^{18}$ Moreover, various transaction costs affect the outcome of the structuring decision. ${ }^{19}$

In addition to business considerations and transaction costs, structuring of an acquisition will also depend upon regulatory costs. Such costs assume three forms: compliance costs, liability costs, and timedelay costs. SEG filings, legal fees, and corporate personnel expenses

12. I.R.C. $\$ 368(a)(1)(A)$. A type-A reorganization is a statutory merger in which the acquirer's stock is issued to the acquired's shareholders.

13. I.R.C. $\$ 368(\mathrm{a})(\mathrm{I})$ (B). A type-B reorganization occurs when the acquirer issues voting stock to the acquired's shareholders in return for their voting stock in the acquired. In general, this acquisition form is less frequently used, because it does not "by itself eliminate the possibility of an unacquirable minority interest." Pugh \& Samuels, Tax-Free International Corporate Combinations under New Sections 367 and 1491, 30 Tax LAw. 263, 267 (1978).

14. I.R.C. $\$ 368(a)(1)(C)$. A type-C reorganization is a sale of substantially all of the acquired's assets in which the acquired receives stock of the acquirer. The problems in. herent in having to transfer corporate assets individually make use of this type less frequent. Pugh \&: Samuels, supra note 13, at 267.

15. See Pugh \& Samuels, supra note 13, at 43. The Department of Commerce study found that several aspects of the form of consideration affect the structuring decision, including foreign capital outflow restrictions, relative cash position and capital structure of the acquirer, and the cost and terms of available capital. 5 Foreign Direcr InvestMent, supra note 2 , at $\mathrm{H}-33$ to $\mathrm{H}-34$.

16. In a tax-free acquisition, the acquirer receives as a carryover basis in the stock or property, its basis in the hands of the acquired. I.R.C. $\$ 362(b)$. The acquirer, however, will often desire a step-up in basis of assets purchased in order to attain a higher depreciation allowance during its operation of the business. This would dictate a cash acquisition of assets rather than a purchase or exchange of stock. On the other hand, the acquirer may want to take advantage of the tax history of the acquired; in a tax-free reorganization, the acquiring corporation succeeds to the acquired's net operating loss carryovers. I.R.C. $\$ 381$. A tax-free reorganization may be desired by the acquired's shareholders because of the basis provision. I.R.C. $\$ 358(a)$ (1); see Young, supra note 6, at 12728 (selling shareholders accept lower price than would if transaction taxable).

17. See Kamin \&: Asofsky, Choice of Securities in Corporate Acquisitions-Primarily Tax Factors, in 2 Business Acquisitions: Planning and Practice 719, 719 (J. Herz \& C. Baller eds. 1971). Shareholders who receive stock instead of cash or senior securities will be subject to future fluctuations in the acquiring firm's performance. Id. at 721. Moreover, the acquiring corporation may not want a large block of stock retained by one group. Schmults, supra note 7 , at 64 .

18. Shareholder approval is usually necessary in merger and sale of assets transactions. See, e.g., Del. Code Ann. tit. 8, \$§ 251, 271 (1976).

19. Transaction costs include valuation expenses, see Bangser, Negotiations and Planning, in 1 Business acquistrions: Planning and Practice 1, 10-20 (J. Herz \& C. Baller eds. 1971); negotiating costs, see $i d$. at 31 ; and the risks of the transaction collapsing, see Acquisition and Merger Negotiation Strategy 170-71 (M. Strage ed. 1971). 
comprise compliance costs. The risk of subsequent disputes and litigation comprises liability costs. Time-delay costs are incurred when regulations postpone consummation of the transaction. ${ }^{20}$ Regulation, from this viewpoint, is not extraneous to the structuring decision, but appears as a cost within it. When regulations treat classes of acquirers disparately, their respective regulatory costs will differ. That disparity will affect their structuring decisions even if the other cost factors do not vary.

\section{B. Regulatory Discrimination}

Several tax and securities regulations increase the regulatory costs of structuring securities acquisitions for foreign acquirers, but not for domestic acquirers.

\section{Tax Provisions}

Two sections of the Internal Revenue Code are particularly burdensome to foreign acquirers: sections 367(a) and 368. Section 367(a) requires a ruling from the Internal Revenue Service (IRS) on certain tax-free exchanges ${ }^{21}$ involving transfers of property from persons in the United States to foreign corporations. Under Treasury regulations, moreover, all tax-free securities acquisitions of domestic corporations by foreign corporations require an IRS ruling. ${ }^{22}$ If the parties do not obtain such a ruling within a specified period ${ }^{23}$ the transaction will be taxable. ${ }^{24}$ IRS guidelines specify the requirements for tax-free treat-

20. Timing is a key factor in successful acquisition transactions, especially those indexed to market values. 5 Foreign Direcr Investment, supra note 2, at H-33. Significant time delays can be involved in securing necessary IRS rulings and in preparing and gaining approval of SEC registration. Young, supra note 6 , at $126,128$.

21. I.R.C. $\$ 367$ (a) (specifying exchanges under six sections of Code that require IRS ruling). See Feinschreiber, Outbound Transfers-The Procedural Aspects, 5 INT'L Tax J. 137, 137-38 (1978) (listing types of outbound transactions).

22. Treas. Reg. $\$ 7.367$ (a)-(1) (1977). The ruling requirement is designed to minimize the tax avoidance potential of the expatriation of appreciated assets or inventory from the United States tax jurisdiction. See H.R. ReP. No. 658, 94th Cong., 1st Sess. 242, reprinted in [1976] U.S. CODE CoNc. \& AD. News 2897, 3138 [hereinafter cited as 1976 HOUSE REPORT].

23. The period is 183 days after the beginning of the transfer. I.R.C. $\$ 367$ (a); see Alpert \& Feingold, Tax Return Act toughens foreign transfer provisions of 1491 and liberalizes 367, $46 \mathrm{~J}$. TAx. 2, 6-7 (1977) (unclear when "beginning" of transfer occurs).

24. Failure to comply with $\$ 367$ (a) does not block the exchange. Rev. Rul. 67-192, 19672 C.B. 140. The foreign corporation loses its "corporation" status, which simply removes the tax-free nature of the transaction normally available under the applicable Code sections. $I d$. This consequence is severe, however, if a major purpose of the transaction's structure was to attain tax-free treatment. To protect itself, an acquired corporation would obviously agree to such an acquisition only if it is conditional upon receiving a favorable IRS ruling. The practical effect of not receiving a favorable ruling thus would be to abort the transaction. 
ment in type-B and type- $\mathrm{C}$ foreign acquisitions, ${ }^{25}$ including the possible imposition of a toll charge in the latter case. ${ }^{26}$ Type-A statutory mergers are not available to foreign acquirers. ${ }^{27}$

These Internal Revenue Code provisions subject foreign acquirers to regulatory costs that domestic acquirers do not bear. The compliance costs of the transaction are increased under any acquisition form adopted: a section 367(a) ruling must be obtained; a toll charge may be required;28 and, in a merger, a domestic subsidiary must be incorporated.

These tax regulations also impose additional liability risks on the foreign acquirer. An unfavorable ruling will cause the acquired cor-

25. Rev. Proc. 68-23, 1968-1 C.B. 821. Type-B exchanges of voting securities will normally receive a favorable ruling, provided that the acquired domestic corporation's shareholders do not obtain a controlling interest in the acquiring foreign corporation and that the assets of the acquired domestic corporation do not consist primarily of stock or securities. $I d$. $\$ 3.03(1)(\mathrm{d})$. "Controlling interest" means more than $50 \%$ of the total voting stock. Id. In cases in which the level of post-transaction ownership is $80 \%$ or more, the guidelines for section 351 transactions apply. Id. $\$ 3.02(1)(\mathrm{d})$.

26. A type-G sale of assets will receive a favorable ruling if the domestic corporation agrees to include in its gross income for the current year an "appropriate" amount to reflect the gain realized due to the appreciation of the assets transferred. $I d . \$ 3.03(1)$ (a). The guidelines provide that type-C reorganizations will be given the same treatment as section 351 transactions. Type-C transactions are seldom free of toll charges. See Nicholson, Farber, Gewanter, \& Samuels, A Panel Discussion, 34 N.Y.U. INsT. Fed. Tax. 925, 940 (1976) (remarks of Leslic Samuels) (part of symposium entitled "Foreign Entities in the United States") [hereinafter cited as Panel Discussion].

The amount of this toll charge is left to the discretion of the IRS. Rev. Proc. 68-23, 19681 C.B. 821, allows the IRS to set the income figure that the acquired must include before section 367 approval will be given. The taxpayer has no real recourse from an adverse determination. Although the acquired corporation has the right to a review of the IRS ruling, I.R.C. $\$ 7477(a)$, the exchange must have begun before it can request a declaratory judgment on the ruling, I.R.C. $\$ 7477(b)(3)$. Although the transfers can be conducted on the stipulation that they will be reversed if the final ruling is unsatisfactory, this requirement imposes large compliance costs and liability-risk costs on the structuring decision.

27. The regulations require that a merger be effected pursuant to domestic corporation laws. Treas. Reg. $\$ 1.368-2(b)(1)$. Some states explicitly authorize mergers involving entities incorporated abroad. See, e.g., Colo. Rev. Stat. ANn. \$ 7-9-114 (1973); N.J. Stat. AnN. $\$ \S$ 14A: 1-2(j), 14A: 10-7(1) (1969). Other states explicitly prohibit such mergers. See, e.g., ALA. Code tit. 10, $\$ 10-2-182$ (1977); MD. CoRp. \& Ass'Ns Codr ANN. $\$ \S 3-101(b), 3-102(a)(2)$ (1975). A number of other states and the Model Business Corporation Act are ambiguous; their merger provisions fail to distinguish between entities incorporated in other states and entities incorporated abroad. See, e.g., ILL. ANN. STAT. ch. 32, $\$ 157.69 \mathrm{a}$ (Smith-Hurd 1954); Tex. Rev. Giv. Stat. ANN. tit. 31, art. 5.07A (Vernon 1956); ABA-ALI Model Bus. CORP. ACT $\$ 2(b)(1970)$.

A foreign acquirer can accomplish a type-A merger only by merging the acquired domestic corporation with a domestic subsidiary of the acquiring foreign firm. This can be accomplished by either a direct subsidiary merger, see I.R.C. $\$ 368(a)(2)(D)$, or a reverse subsidiary merger, see I.R.C. $\$ 368(a)(2)(E)$. The policy reasons underlying the restriction of foreign acquirers to such circuitous merger structures are unclear. See Panel Discussion, supra note 26, at 939 (remarks of Leslie Samuels).

28. The acquired in a foreign acquisition is forced to recognize gains prior to any realization. See note 26 supra. In the domestic acquisition context no such requirement exists. 
poration's shareholders to recognize gains but not losses. ${ }^{29}$ In a type-C transaction, any acquisition begun prior to a section 367(a) ruling may incur an undetermined toll charge. Both possibilities magnify the downside risks of the structuring decision.

The foreign acquirer, moreover, must bear time-delay costs not borne by domestic acquirers. The prudent acquirer would seek a ruling in advance. ${ }^{30} \mathrm{~A}$ type-A transaction must await the incorporation of a domestic subsidiary. Thus, additional time will elapse between the initial planning and the consummation of the acquisition.

\section{Securities Regulations}

A decision to finance an acquisition with securities will involve the foreign acquirer in a public offering, which must be registered under the Securities Act. ${ }^{31}$ Registration entails both initial disclosure and subsequent reporting of the issuer's status. ${ }^{32}$ In addition, the acquirer will become subject to domestic liability provisions, ${ }^{33}$ particularly Rule $10 \mathrm{~b}-5 .^{34}$ Although the foreign acquirer is treated no differently from the domestic acquirer under the Securities Act, ${ }^{35}$ its different relation-

29. Rev. Rul. 67-192, 1967-2 C.B. 140; see Ginsburg, Acquisitive Reorganizations, in SEC and Tax Consequences of Corporate Acquisitions 2d 7, 119 (M. Ginsburg \& $\mathrm{L}$. Schneider eds. 1970).

30. Sturm, Taxation of the Foreign Investor in the United States, 55 TAxEs 542, 560 n.175 (1977). This is particularly true in type-C transactions, in which the decision to structure the acquisition on a tax-free basis may depend upon the size of the toll charge.

31. Securities Act $\S 5$, 15 U.S.C. $\$ 77$ e (1976). See note 8 supra (securities used in securities acquisitions must be registered). Because it is unlikely that the acquired corporation would accept securities in a private offering and agree never to distribute them, at some point the foreign acquirer will have to register under the Securities Act. See Georgetown U. School of LAw, Institute for INTERNational and Foreign Trade Law, Legal Environment for Foreign Direct Investment in the United States 107 (1972) [hereinafter cited as GEORGETOWN STUDY].

32. See Securities Act $\S 5,15$ U.S.C. $\S 77 \mathrm{e}$ (1976); Exchange Act $\S 15(d)$, 15 U.S.C. $\$ 780$ (d) (1976). The purpose of the Securities Act is "[t]o provide full and fair disclosure of the character of securities sold in interstate and foreign commerce and through the mails, and to prevent frauds in the sale thereof. . . ." Securities Act, Pub. L. No. 73-22, preamble, 48 Stat. 74 (1933).

33. Securities Act $\$ 5$, I5 U.S.C. $\$ 77 \mathrm{e}$ (1976) (liability for failing to register properly); id. $\$ 10(\mathrm{~b}), 15$ U.S.C. $\$ 77 \mathrm{j}(\mathrm{b})(1976)$ (liability for registration deficiency); id. $\$ 11 \mathrm{a}, 15$ U.S.C. $\$ 77 \mathrm{k}(\mathrm{a})$ (1976) (liability to private civil suit for material factual deficiencies in registration statement); $i d$. $\$ 17(\mathrm{a}), 15$ U.S.C. $\$ 77 \mathrm{q}(\mathrm{a})$ (1976) (criminal liability for fraudulent offer or sale); Exchange Act $\$ 9,15$ U.S.C. $\$ 78 \mathrm{i}$ (1976) (liability for manipulation of securities prices); id. $\S 10,15$ U.S.C. $\$ 78 \mathrm{j}$ (1976) (liability for use of manipulative or deceptive devices); id. $\$ 14(\mathrm{e}), 15$ U.S.C. $\$ 78 \mathrm{n}(\mathrm{e})$ (1976) (liability for misleading statements in tender offers); $i d . \S 16(\mathrm{~b}), 15$ U.S.C. $\$ 78 \mathrm{p}(\mathrm{b})$ (1976) (liability for profits from insider transactions within six-month period); $i d$. $\$ 18(a)$, 15 U.S.C. $\$ 78 \mathrm{r}$ (a) (1976) (liability to private suit for material factual deficiencies in SEC filings).

34. 17 C.F.R. $\$ 240.10 \mathrm{~b}-5$ (1979).

35. L. Rappaport, SEG Accounting Practice and Procedure 31.36 (3d ed. 1972). 
ship to the American regulatory framework imposes greater regulatory costs on it.

In addition to the liability provisions of American securities laws and associated liability risks that cause some concern, ${ }^{36}$ compliance costs also pose a substantial obstacle to the foreign acquirer. Foreign acquirers have difficulty in conforming financial reports to SEC requirements. Accounting principles vary between countries. ${ }^{37}$ Moreover, use of independent auditors is rare outside the United States. ${ }^{38}$ Foreign issuers encounter additional difficulties in completing the narrative portions of registration statements. ${ }^{39}$ The SEC's common requirement of a statement of world and national economic conditions affecting the registrant further adds to the foreign acquirer's regulatory burden. ${ }^{40}$

Although the SEC has recognized these difficulties, it has failed to

36. Foreign concern with liability provisions centers on the Exchange Act, particularly the per se civil liability provisions of section 16(b), 15 U.S.C. $\$ 78 p(b)$ (1976). See Stephens, Reevaluation of Disclosure Requirements for Foreign Issuers: Securities Exchange Act of 1934, 45 GeO. WASH. L. Rev. 494, $501-02$ (1977). Rule 13a12-3, 17 C.F.R. $\$ 240.3 a 12-3$ (1979), exempts foreign issuers who report on Form 20-F from the operation of section 16 .

Although uncertainty in the evolution and application of Rule 10b-5, see Buschman, Antifraud and the Water's Edge: Transnational Transactions, Rule 10b-5, and the Federal Securities Code, 7 SEC. REg. L.J. 232, 247-64 (1979) (summarizing judicial interpretations of application of $10 \mathrm{~b}-5$ to foreign issuers), may concern foreign acquirers, it does not appear that liability under the Rule has a significantly disparate impact upon the regulatory costs of structuring a foreign securities acquisition. Domestic and foreign acquirers are equally subject to the Rule. Unlike the reporting procedures, therefore, Rule 10b-5 does not impose immediate extra costs on foreign acquirers. Moreover, although the modes of regulation vary, many nations-including those in which the most active acquirers reside-do not tolerate misuse of inside information. See, e.g., Mulrinational APproaches-Corporate INSIDERs 23.63 (L. Loss ed. 1976); International Securities Project, 30 Bus. LAw. 585, 609-10, 630-31, 658, 667 (1975).

The EEC Commission has proposed a securities code that would require that the public be fairly and adequately informed and that no particular class of persons be permitted to attain a privileged position in the market. Recommendation Concerning a European Code of Conduct Relating to Transactions in Transferable Securities, 20 O.J. Eur. Comm. (No. L 212) 37, CII Encyclopedia of European CoMmunity LAW $\$ \$$ C5-476 to -483 (1977).

Although Rule 10b-5 does apply to foreign issuers, commentators have not portrayed such liability as a problem for foreign acquirers. When a foreign acquirer's domestic regulatory system has nothing approximating such liability, the impact of possible Rule $10 \mathrm{~b}-5$ violations on the structuring decision will be greater.

37. See L. Rappaport, supra note 35, at 31.I; Price Waterhouse International, A SURveY IN 46 Countries (1975); Stephens, Reevaluation of Disclosure Requirements for Foreign Issuers: Securities Act of 1933, 45 Geo. WASH. L. REv. 135, 146 (1977).

38. Stephens, supra note 37, at 156-57. See L. RAPPAPORT, supra note 35, at 31.21 (concept of independence abroad often differs from that in United States).

39. Difficulties arise in distinguishing lines of business, Investment Regulation, 11 LAW \& PoL'y INT'L Bus. 255, $270-73$ (1979), describing management remuneration, Bator, Offerings of Foreign Securities in the United States, in SIXTH ANNUAI INSTITUTE ON Securities Regulation 309, 324 (1975); Stephens, supra note 37 , at 159, or specifying shareholder control, Bator, supra, at 324; Stephens, supra note 37, at 161-62.

40. See Rule 408, 17 C.F.R. $\$ 230.408$ (1979); Stephens, supra note 37 , at 163.64 . 


\section{Foreign Acquisitions}

alleviate them. ${ }^{41}$ Instead of providing separate forms or regulations for foreign registrants under the Securities Act, ${ }^{42}$ SEC policy has been to accommodate foreign issuers on a case-by-case basis. ${ }^{43}$ The need to await specific SEC advice increases the acquirer's time-delay costs. ${ }^{44}$

The structural differences between a foreign and domestic acquirer's relationship to the American regulatory framework accentuate the foreign acquirer's compliance costs. ${ }^{45}$ Normally, domestic acquirers have previously raised capital and structured their financial reporting systems in accordance with SEC and American accounting requirements. ${ }^{40}$ Because domestic acquirers are familiar with the financial and narrative reports required, ${ }^{47}$ their compliance costs in an acquisition will stem primarily from updating their prior reports.

The compliance costs of a foreign acquirer, by contrast, will be equivalent to those incurred in a domestic acquirer's initial encounter with SEC regulation..$^{48}$ The acquisition registration will often be the foreign acquirer's first contact with the American regulatory framework. ${ }^{49}$ Although the SEG is willing to make certain accommodations, the requisite negotiations add to the time-delay costs. These added regulatory costs can skew the structuring decision away from the securities technique in cases in which a domestic acquirer would not be under

41. Securities Act Rel. No. 5316, 37 Fed. Reg. 23,631 (1972); see Borden, supra note 9, at 20.

42. Securities Act Rel. No. 6157, 44 Fed. Reg. 70,130 (1979); see Garrett, Is the SEC a Barrier to New York's Role in International Finance? SEC. REG. \& L. REP. (BNA), June 19, 1974, at D-1.

43. Securities Act Rel. No. 6157, 44 Fed. Reg. 70,130 (1979); Garrett, supra note 42, at D.2. The SEC has in some cases permitted use of foreign financial statements, with reconciliation to United States standards in the footnotes. Nathan, stipra note 6, at 46 . The SEC has also shown some flexibility on the auditor independence requirement. Id. Auditors must not be employees of the registrant, and any holdings of securities in the registrant must be in the process of being sold. L. RAPPAPORT, supra note 35 , at 31.22 to .23. The SEC has not been flexible, however, about differences in auditing standards in important areas, such as testing accounts receivable and inventories. The SEC has also been inflexible on the need for consolidated financial statements. Nathan, supra note 6, at 46.

44. See Young, supra note 6, at 128; cf. L. RAPPAPORT, supra note 35, at 31.19 (compliance with auditor independence standards should be discussed with SEC in advance of filing).

45. See Damm, The Economic Aspects of European Direct Investment in the United States, in The Multinational Corporation in the Wordd Economy 35, 40 (S. Rolfe \& W. Damm eds. 1970).

46. See Borden, supra note 9 , at 25. See note 10 supra.

47. See L. RAPPAPORT, supra note 35, at 31.18.

48. See id. at 31.23; Nathan, supra note 6 , at 50 (registration costs are high and procedure involves substantial time and effort).

49. See Comment, Foreign Acquisitions in the United States: $A$ Challenge to the Potential Competition Doctrine, 44 FordhaM L. REv. 301, 318-19 (1975). 
such pressure. ${ }^{50}$ This differential impact on foreign acquirers may, along with other factors, explain the virtual absence of securities acquisitions by foreign corporations.

\section{The Standard of Regulative Neutrality}

The American regulatory treatment of foreign securities acquisitions must be examined in the context of United States policy on international capital movements. That policy dictates a standard of regulative neutrality that ensures nondiscriminatory treatment of foreign investors. This standard could be implemented by a criterion of effective parity that would guarantee that American regulations do not impede foreign investors to a greater extent than domestic investors.

\section{A. United States Policy on International Capital Movements}

The United States has been a strong advocate of international free trade since the Second World War. ${ }^{51}$ The theory underlying this policy is that the world market operates most efficiently and fairly when unencumbered by artificial governmental restrictions..$^{52}$ One of the po-

50. See Nathan, supra note 6 , at 50 (securities regulations result in foreigners unwillingness to use securities for acquisition). It is the additional acquisition costs, not the initial regulatory establishment costs, that are relevant to the structuring decision. Cf. W. Nicholson, Microeconomic Theory: Basic Principlis and Extensions 480 (2d ed. 1978) (sunk costs irrelevant to profit-maximizing decision).

51. The United States has long welcomed foreign direct investment. See Katz, Foreign Direct Investment in the United States, in 1 United STATES INTERNATIONAL Economic Policy in an Interdependent World 965, 966 (1971); Note, An Evaluation of the Need for Further Statutory Controls on Foreign Direct Investment in the United States, 8 VAND. J. Transnat'L L. 147, 152-53 (1974). The United States became a net exporter of capital only after World War I. Weintraub, Why the Uniled States Welcomes Foreign Investments, in Proceedings of the Conference on Foreign Direct Investment in the Unittd STATES 8,9 (1970).

During some periods, the United States has retreated from this policy. See, e.g., Niehuss, Foreign Investment in the United States: A Review of Government Policy, 16 VA. J. INT'L L. 65, 65 (1975); Vagts, The Corporate Alien: Definitional Questions in Federal Restraints on Foreign Enterprise, 74 HARv. L. Rev. 1489, 1493 (1961).

52. U.S. Comm'n on International. Trade and Investment Policy, Report to the President: United States International Economic Policy in an InTERdependent World 178 (1971) [hereinafter cited as CoMmission REPORT]; Weintraub, supra note 51, at 9. The theory imports a conceptual distinction between "artificial" factors, such as governmental regulation, and "real" factors, presumably economic forces. Although this Note argues only that United States policy and regulation should be consistent, it might be that the theory underlying this policy is not the best solution to the problem of world market efficiency. According to the theory of second best, unless all of the optimal conditions for economic efficiency can be attained, it may not be desirable to satisfy any individual optimal condition. See Lipsey \& Lancaster, The General Theory of Second Best, 24 REv. ECoN. STUd. 11 (1956). Thus, if foreign governments maintain restraints on international trade, it is possible that the United States should not remove its tariffs and capital controls. A second-best solution would have to be derived, given the violations of the 
litical objectives of this policy has been facilitation and protection of United States investment abroad..$^{33}$

The policy has been codified in various multinational and bilateral agreements. The Code of Liberalisation of Capital Movements, promulgated by the Organisation for Economic Co-operation and Development (OECD), explicitly provides that all members shall allow certain specified transactions, ${ }^{54}$ including the "acquisition of full ownership of an existing enterprise" 55 and the "[a]dmission of foreign securities on the domestic capital markets." "जo The General Agreement on Tariffs and Trade (GATT)' $\mathrm{s}^{57}$ emphasis on reducing governmental intervention in the international trading arena ${ }^{58}$ also reflects this United States

optimal conditions. Usually, the second best general solution is so complex that the type of adjustment required to improve efficiency is impossible to determine. See F. SCHERER, Industrial Market Structure and Economic Performance 25 (1970); cf. Buchanan, External Diseconomies, Corrective Taxes, and Market Structure, 59 AM. Econ. REv. 174 (1969) (example of indeterminable second best solution). The current American response to violations of optimal conditions would be indeterminable.

53. Brownell, Foreign Investment in the United States Should not be Restricted, in Current Legal Aspects of Foreign Investment in the United States 57, 58 (D. Evans, J. Forry, V. Narcisi, \& M. Perlberger eds. 1976) (policy benefits U.S. corporations investing abroad); see Note, supra note 51, at 154 (liberal trade policy creates expanded export markets).

54. Organisation for Economic Co-Operation and Development, Code of Liberalisation of Capital Movements art. 2(a) (1973 ed., updated June 1978) [hereinafter cited as Liberalisation CODE].

55. Id. Annex A, List A, $\S \mathrm{I}(\mathrm{A})(\mathrm{I})$; cf. id. Annex A, List A, $\S \mathrm{I}(\mathrm{A})(3)$, remark (ii) (listed transactions free unless they would have exceptionally detrimental effect on interest of country). Remark (ii) appears to allow some pre-investment screening of individual investment decisions. See Rising Tide, supra note 1 , at 579. This exception does not provide for systematic discrimination against transactions covered by List $A, \S 1$. The United States has attached a reservation to Article 2 concerning such transactions. The reservation applies to statutory restrictions on alien investment in or control of certain communication, transportation, and energy industries. LIBERALISATION Code, supra note 54, at 109. The United States has made no general reservations, however, to such transactions or to any other part of the Liberalisation Code.

56. Liberalisation Code, supra note 54, Annex A, List A, § III(B). The remark to this section requires that securities admitted must have been "introduced in a recognised security market of the country of issue" and must be subject to the regulations of the domestic market. Id. Annex. A, List A, $\S$ III(B), remark. This second condition, however, must be read in conjunction with the remark's prohibition of regulations that discriminate against foreign securities.

57. Opened for signature Oct. 30, 1947, 55 U.N.T.S. 187. As of January 1, 1978, 83 parties had joined the treaty. General Agreement on Tariffs and Trade, Basic InstruMENTS ANd Selected Documents vii (Supp. No. 24, 1978).

58. See Weiss, The General Agreement on Tariffs and Trade: An Assessment, in 2 United States International Economic Policy in an Interdependent World 451,452 (1971) (discussing benefits of reduced governmental intervention).

A common theory appears to underlie both capital-movements policy and trade policy. See, e.g., de Saint Phalle, Overview of Legal Problems Faced by a Foreign Business Enterprise Wishing to Establish a Base in the United States, in Current Legat Aspects of Foreign Investment in the United States 162, 163 (D. Evans, J. Forry, V. Narcisi, \& M. Perlberger eds. 1976); Note, supra note 51, at 157. 
policy. ${ }^{59}$ In addition, the United States has ratified Friendship Navigation and Commerce treaties with eleven countries. ${ }^{60}$ Those treaties embody the "national treatment" principle, which prohibits the federal government from imposing more severe restrictions on the nationals of the other party than it does on its own citizens. ${ }^{61}$

Recent executive-branch activities reflect the policies underlying these international agreements. ${ }^{62}$ In 1976 the President endorsed the OECD Declaration on International Investment and Multinational Enterprise. ${ }^{63}$ Executive-branch statements on tax and securities regulation have reaffirmed that policy. ${ }^{64}$ Despite some public and congressional concern over foreign direct investment, ${ }^{65}$ Congress has not

59. Although the Senate has never ratified GATT, the Congress has frequently authorized trade negotiations under its aegis. See, e.g., Trade Expansion Act of 1962, Pub. L. No. 87-794, $\$ 201,76$ Stat. 872 (authorized negotiations for trade agreements and reforms); Trade Act of 1974, Pub. L. No. 93-618, $\S \S 121-127,88$ Stat. 1978 (codified at 19 U.S.C. $\$ \S 2131-2137$ (1976)) (authorized negotiations for reform of GATT).

60. Note, supra note 1 , at 137 n.221. The United States currently has such treaties with Israel, Japan, Federal Republic of Germany, Nicaragua, The Netherlands, Republic of Korea, Mussat \& Oman, France, Luxembourg, Togo, and Thailand. Rising Tide, supra note 1 , at $568 \mathrm{n} .63$ (treaties assuring foreign investors right of access).

61. Rising Tide, supra note 1 , at 569; Note, supra note 1 , at 137 . These treaties all explicitly provide that foreign investors have the right to acquire majority interests in United States companies. Id. at 568-69.

62. See, e.g., International Economic Report of the President 84 (1977) (affirming policy of reducing governmental restrictions); COMMIssION REPORT, supra note 52, at 178 (recommending reduction of artificial governmental incentives and barriers to foreign investment). The only recent exception to this trend was President Johnson's imposition of certain capital controls. See Exec. Order No. 11,387, 33 Fed. Reg. 47 (1968). Under the terms of this Order, the Secretary of Commerce established the Office of Foreign Direct Investment in the Department of Commerce, which issued regulations restricting the outflow of capital from the United States to reduce the United States balance of payments deficit. See Note, The Foreign Direct Investment Regulations, 1973: Balance of Payments Remedy or Regulation of Multinational Corporations? 11 SAN DiEGo L. REv. 267, 267, 270-74 (1973).

63. Internationat Economic Report of the President, supra note 62, at 1; see ORGANISATION FOR ECONOMIC CO-OPERATION AND DEVELOPMENT, INTERNATIONAL INVESTMENT AND Multinational Enterprises $\$$ II (1976) (endorsing national-treatment principle).

64. See Commission RePort, supra note 52, at 179 (taxes should not influence foreign investment decisions); Garrett, supra note 42, at D-1 (SEC sees U.S. policy as encouraging free flow of capital among nations); Greater Attention to Internationalization of Securities Urged by Williams, SEc. REg. \& L. REP. (BNA), June 20, 1970, at A-19 (reaffirming free capital-movements policy) [hereinafter cited as Williams].

65. This concern has been acute in the area of land ownership. The jump in Japanese investment in Hawaiian real estate sparked debate on limiting foreign investment in the United States. See Note, U.S. Regulation of Foreign Direct Investment: Current Develop. ments and the Congressional Response, $15 \mathrm{~V}_{\mathrm{A}}$. J. INT'L L. 611 (1975). Another source of this concern was the 1973 Arab oil boycott. See de Saint Phalle, supra note 58, at 167. The concern is that foreign acquirers will exercise their control without considering domestic interests, see, e.g., id. at 167-68 (Arab takeovers and political blackmail); Brownell, supra note 53, at 59 (undesirable socio-political consequences), or to achieve foreign political goals, see, e.g., McCarthy, Government Regulation of Foreign Investment in the United States, in Current Legal Aspects of Foreign Investment in the United States 84, 86 (1976). Those commentators, however, believe that such fears are unrealistic. 
opposed executive-branch policy on international capital flows. ${ }^{66}$

In accordance with this free-trade policy, the United States has not restricted foreign acquisition of domestic corporations for cash. ${ }^{67}$ For several reasons, neither should the government impede securities acquisitions. First, the greater availability of securities acquisitions would increase the number of avenues for entering the United States capital market. ${ }^{68}$ That development could facilitate the further influx of technology ${ }^{68}$ and foreign investment. ${ }^{70}$

Second, because securities acquisitions facilitate capital mobility, their increased availability would improve world economic efficiency. Increased availability would allocate world capital more efficiently by providing another path for investment. ${ }^{71}$ Increased capital mobility would encourage the internationalization of management and decisionmaking.72 Equity ownership would be diversified to a greater extent than cash acquisitions permit. ${ }^{73}$

66. Although several bills have been introduced in Congress to restrict foreign investment, none has become law. See, e.g., H.R. 158, 96th Cong., 1st Sess. (1979) (authorizing President to prohibit foreign direct investment for reasons of national security, foreign policy, or economic protection); S. 1539, 96th Cong., 1st Sess. (1979) (prohibiting foreigners from acquiring financial institutions with assets over $\$ 100$ million prior to April 1, 1981). $B u t$ cf. Depository Institutions Deregulation and Monetary Control Act of $1980, P u b . L$. No. 96-221, $\S 902,96$ Stat. 193 (to be codified at 12 U.S. $\$ 3101$ note) (requiring Federal Reserve Board moratorium of one year on acquisitions of United States banks by foreign parties).

Congress has passed three laws that require collection of data on foreign investment in the United States. Foreign Investment Study Act of 1974, Pub. L. No. 93-479, 88 Stat. 1450 (codified at 15 U.S.C. $\$ 78 \mathrm{~b}$ note (1976)); International Investment Survey Act of 1976, Pub. L. No. 93-472, 90 Stat. 2059 (codified at 22 U.S.C. $\$ \$ 3101-3108$ (1976)); Agricultural Foreign Investment Disclosure Act of 1978, Pub. L. No. 95-460, 92 Stat. 1263 (to be codified at 7 U.S.C. $\$ \$ 3501-3508$ ). These Acts provide only for information gathering, see Note, supra note 1 , at 141 , and do not indicate any change in United States policy toward international capital flows. Section 2(c) of the International Investment Study Act of 1976, Pub. L. No. 93.479, 88 Stat. 1450 (codified at 22 U.S.C. $\$ 3101$ (c) (1976)), explicitly states that the Act is not intended to restrain or deter foreign investment in the United States.

67. Foreigners have a number of financing alternatives. They may have cash on hand or can borrow from foreign sources. They may also go to the Eurodollar market. Moreover, the regulations on bank loans, even in borrowing from United States banks, do not distinguish between foreign and domestic borrowers. See Regulation U, 12 C.F.R. $\$ 221.1$ (a) (1979) (margin requirement for all loans secured by stock). One study concluded that future direct investments will continue to be made using cash, obtained predominantly from foreign sources, as consideration. I Foreign DiRECr INVESTMENT, supra note 2, at 120.

68. This additional avenue might simply alter the distribution of acquisition structures between cash and securities types, resulting in no net increase in foreign acquisitions; alternatively, it might increase the actual number of acquisitions.

69. See Georgetown StUdy, supra note 31, at 2; Weintraub, supra note 51, at 11 .

70. See Weintraub, supra note 51, at 9 . The United States will need additional sources of capital in the near future. See Brownell, supra note 53, at 58-59; de Saint Phalle, supra note 58 , at 164 .

71. See Weintraub, supra note 51 , at 9.

72. See Ball, Address, in Proceedings of the Conference on Foreign Direct InvestMINT IN THE UNITED STATES 52, 59 (1970).

73. See id. at 59 (dispersion of equity ownership). Securities acquisitions increase the 
Third, the increased availability of the securities acquisition technique would further the internationalization of securities markets, a professed goal of the United States. ${ }^{74}$ Such transactions would add to the dispersion of securities ownership, thereby encouraging familiarity with securities markets of other countries and thus facilitating capital movements. ${ }^{75}$ The increase in the number of international securities transactions could also raise international disclosure standards. ${ }^{70}$. These three factors suggest that treatment of foreign securities acquisitions should be consistent with general United States free-trade policy.

\section{B. The Criterion of Effective Parity}

These policies suggest a standard against which the treatment of foreign acquirers should be assessed. A standard of regulative neutrality would implement stated American policy and would be consistent with its underlying world economic efficiency theory. The standard would not require the elimination of all restrictions on capital movements; rather, it would simply provide that treatment of capital transactions not vary with the nationality of the acquiring party.

The standard of regulative neutrality would be analogous to the principle of tax neutrality. Under that principle, the choice of location for investment of capital should not be influenced by differences in tax burdens imposed by various jurisdictions. ${ }^{77}$ The underlying premise

number of parties holding securities of foreign corporations, whereas cash acquisitions merely cause ownership to change hands.

The danger of United States shareholders being frozen-out of participation after a foreign merger is slight. Mergers within the European Economic Community must leave original shareholders with an equity participation in the new entity. A cash "equalization payment" to the merged company's shareholders cannot exceed $10 \%$ of the nominal value of the shares issued. Third Council Directive of October 9, 1978, art. 4(1), 22 O.J. Coms. EUR. (No. C885), [1979] Comm. MKr. Rep. (CCH) I 1381. See note 2 supra (most acquirers are nationals of EEC countries).

These various effects, while not necessarily unique to the increased availability of securities acquisitions, are products of an increase in international capital movements; wider use of securities in acquisitions would promote such an increase. See note 68 supra; Ball, supra note 72, at 58-60 (discussing role of multinationals in freeing up world trade).

74. See note 64 supra.

75. See Ball, supra note 72 , at $56-57$ (discussing foreign securities acquisition that created active United States market in foreign parent's common stock).

76. See Stephens, supra note 37 , at 170 (discussing SEC participation in international efforts to raise disclosure standards). As securities markets become more interdependent, one nation cannot operate its market without considering other markets. See Williams, supra note 64, at A-19. A foreign acquirer could conduct a securities acquisition of a domestic corporation outside the United States regulatory framework. Offshore equity markets, analogous to the Eurodollar market, might someday enable acquirers to completely avoid American regulation. $C f$. R. Aliber, International Money Game 145-59 (3d ed. 1979) (Eurodollar market operating outside regulatory jurisdictions).

77. P. Musgrave, United States Taxation of Foreign Investment Income 109 (1969) (defining tax neutrality). 
of the tax neutrality principle is that worldwide efficiency in resource allocation is optimized by nondiscriminatory tax treatment of capital flows. ${ }^{78}$ The regulative-neutrality standard would adopt that premise ${ }^{79}$ and apply it to regulations affecting foreign acquirers.

Under the regulative-neutrality standard, an investment decision should be governed by the relevant economic and business variables, not by the existence of disparate regulatory costs. The goal of the standard would be to produce a situation of decisional neutrality in which investments of foreigners would not be impeded to a greater extent than those of domestic parties.

The standard of regulative neutrality could be implemented by application of a criterion of effective parity. Particular regulations would satisfy the standard if the regulatory costs involved in an investment decision were equal for foreign and domestic parties. ${ }^{80}$ At the same time effective parity must coordinate the aim of the neutrality standard with the other policy goals of the regulations. Deviation from effective parity would be justified only when the most narrow ${ }^{81}$ and

78. Id. at 74-75, 109; cf. Ross, Basic Problems of Taxation of Foreign Direct Investment in the United States, in ProceEdings of the Conference on Foreign Direct Investament IN THE UNITED States 94 (1970) (comments of Arthur Rothkopf) (Foreign Investors Tax Act of 1966, Pub. L. 89-809, 80 Stat. 1539, sought, not to give foreign investors incentive to invest in U.S., but rather to put them on parity with domestic investors.) The tax system should not alter investment-decision considerations of risk and return. P. MusGrave, supra note 77, at 118 .

79. See note 52 supra.

80. "Equivalence" for the purposes of the regulative-neutrality standard cannot be measured quantitatively. Tax neutrality focuses upon a final figure of tax liability for the same investment. See P. MusGrave, supra note 77, at 109. Regulative neutrality, by contrast, would focus upon the underlying costs incurred in complying with the tax and securities regulations in an acquisition. Equivalence in regulatory costs refers to an effectively equivalent-but not identical-regulatory burden on foreign and domestic acquirers: even for two domestic firms, the same acquisition would involve disparate regulatory costs given differences in management efficiency, corporate structure, and other factors.

The effective-parity criterion would focus upon the effect of regulations as a cost in the investment decision. That effect should be considered from the acquirer's standpoint. A rule of formal equal treatment would not necessarily satisfy the criterion of effective parity. When parties maintain different relationships to the regulatory framework, an equal-treatment rule would have disparate impacts on the investment decision. The purpose of interpreting the standard of regulative neutrality by effective parity is not to compensate foreign acquirers for disadvantageous economic or business conditions, but rather to eliminate disparate effects of regulation from the business decision of how to structure an acquisition. The line between neutrality and compensation is a fine one.

81. "Narrowness" refers to the specificity of the behavior sought to be regulated. The "overinclusiveness" theory of statutory invalidity is relevant here, not as a test of constitutionality, but as a test of the practical appropriateness of a prescription. Cf. Perry, Modern Equal Protection: A Conceptualization and Appraisal, 79 Colum. X. Rev. 1023, 1074 n.263 (1979) (discussing substantive due process versus equal protection theories of overinclusiveness); Developments in the Law-Equal Protection, 82 HARv. L. REv. 1065, 1086 (1969) (over-inclusion less tolerable than under-inclusion). 
efficient ${ }^{82}$ regulatory device is used to achieve the specific policy of the regulation. ${ }^{83}$

In sum, the criterion of effective parity could be used to evaluate a particular regulatory framework for its consistency with the policy contained in the standard of regulative neutrality. The test would consist of two inquiries: are the regulatory costs imposed equivalent between two investors; has the most narrow and efficient regulatory device been used to implement the specific regulatory objective?

\section{Achieving Effective Parity in Foreign Securities Acquisitions}

The criterion of effective parity could be applied to the tax and securities regulatory framework governing securities acquisitions. This application suggests several regulatory modifications that would satisfy the standard of regulative neutrality and thus make the treatment of foreign acquirers more consistent with American policy on international capital flows.

\section{A. Amending the Tax Provisions}

Securities acquisitions by foreigners are impeded by the comparatively higher regulatory costs imposed by section 367 (a). ${ }^{84}$ The adoption of an establishment rule would remove this impediment without jeopardizing the anti-tax evasion policy of the Code.

82. "Efficiency" denotes the minimization of regulatory costs in achieving the regulatory policy, and it should be measured from the standpoint of the party affected. If the test is the neutrality of the effect of a regulation on the structuring decision, regulations that add costs to the structuring decision beyond those necessary to achieve the regulatory policy are inefficient. An ancillary consequence of the efficiency requirement is that a certain amount of the cost of regulation may shift to the regulatory agency. See note 134 infra. Precise regulations will involve greater initial promulgation and enforcement costs. The extra costs will shift from the structuring decision of the acquirer to the activities of the regulatory agency. Instead of individual foreign acquirers incurring the added costs with each and every acquisition, the regulatory agency would be able to routinize the procedures and thus raise the efficiency level of the regulation. The regulatory agency would thus assume and minimize the regulatory cost differential between foreign and domestic securities acquisitions.

83. A deviation from the standard of regulative neutrality would be justified only when another policy goal was served and the deviation was as slight as possible. $C f_{\text {. }}$ Breyer, Analyzing Regulatory Failure: Mismatches, Less Restrictive Alternatives, and Reform, 92 HARv. L. REv. 549, 586 (1979) (discussing least restrictive regulatory alternative); Markham, Regulation of International Transactions Under the Commodity Exchange Act, 48 FoRDhAM L. REv. 129, 157-58 (1979) (discussing necessity of using alternative measures to achieve regulatory goals and accommodate international commodities trading).

84. See pp. 1418-19 supra. 


\section{The Establishment Rule}

In securities acquisitions of ongoing United States business entities, the anti-tax evasion policy objective of section $367(a)^{85}$ is not relevant. When the acquired corporation remains established in some form and is engaged in trade or business within the United States, ${ }^{86}$ it will be subject to the domestic corporate tax provisions. ${ }^{87}$ In such a situation, a section 367(a) ruling is unnecessary, for the gain on expatriated appreciated property can be taxed to the remaining entity. ${ }^{88}$ The regulation is over-inclusive and thus violates both the narrow-and-efficient and the equivalent-cost requirements of the effective-parity criterion.

An establishment rule could provide a basis for narrowing the regulations to their specific policy objective and for reducing the foreign acquirer's regulatory costs to a level of parity with domestic acquirers. The rule would operate by distinguishing between securities acquisitions that pose an evasion threat and those that do not. An appropriate definition of "establishment" could be modeled on the jurisdictional concept of permanent establishment ${ }^{89}$ that has been used in double-

85. See note 22 supra $(\S 367$ (a) seeks to prevent permanent non-recognition of appreciated assets transferred abroad).

86. I.R.C. $\$ 882(a)(1)$; see B. Bittker \& J. Eustice, Federal Income Taxation of CoRPorations AND SHAREHolders I 17.02 (4th ed. 1979) (discussing factors that create U.S. business situs).

87. Acquired entities that remain incorporated in the United States, whether in their original form or as foreign-owned subsidiaries, are taxable. I.R.C. $\$ \S 11,1201$. Foreign branches that meet the "engaged in trade or business in the United States" requirement are taxable on corporate income (as provided in I.R.C. $\S 11$ ) and on corporate capital gains (as provided in I.R.C. $\$ 1201$ (a)). I.R.C. $\$ 882(a)(1)$.

88. See Pugh \& Samuels, supra note 13 , at 273 . This overly broad regulatory approach may facilitate IRS enforcement by reducing its costs, see note 82 supra, but it violates effective parity.

Some "leakage" of assets out of the country may occur even when the entity survives the acquisition. The critical fact is that some taxable entity remains within the United States tax jurisdiction. Leakage poses two problems for the IRS. First, the IRS must be able to detect the existence of the leakage. If the entity continues to exist in the United States, then the detection problem is comparable to that with respect to domestic companies. Second, the IRS must be able to enforce a tax deficiency determination. Provided that the entity remains in the United States, this poses no special problem. The allocation provision of section 482, for example, provides a general enforcement mechanism for the prevention of tax evasion through related foreign and domestic corporations. See Note, Multinational Corporations and Income Allocation under Section 482 of the Internal Revenue Code, 89 HARv. L. REv. 1202, 1204 (1976). If the IRS determines that an appreciated asset has been transferred out of the United States' taxing jurisdiction, income is allocated to the domestic entity.

89. See Pugh \& Samuels, U.S. Tax Aspects of Acquisitions of U.S. Corporations by Foreign Corporations, 34 N.Y.U. INsr. FED. TAX 991, 1005 (1976); Pugh \& Samuels, supra note 13 , at 263 n.l. 
taxation treaties ${ }^{90}$ and two European Economic Community (EEC) proposals. ${ }^{91}$ The appropriate rule under the criterion would be that no ruling is necessary if the acquirer intends to maintain a United States business entity. ${ }^{92}$ As in domestic reorganizations, an acquirer could request a ruling in an ambiguous case..$^{93}$

\section{Applying the Establishment Rule}

A type-B transaction that satisfies the establishment rule should be exempted from the ruling requirement. ${ }^{94} A$ type- $B$ acquisition, whether direct or by means of a domestic subsidiary, leaves a corporate entity within the tax jurisdiction of the United States. As in a domestic type-B reorganization, recognition of capital gains would be deferred until a break in the continuity of interest. ${ }^{95}$ The proposed modification leaves both foreign and domestic acquirers with equivalent regulatory costs.

A similar change should be made for type- $\mathrm{C}$ reorganizations that involve a sale of assets to a United States subsidiary of a foreign acquirer. In such cases, title to the assets passes to a domestic corporation. ${ }^{96}$ This is not essentially different from a type-C sale of assets between two domestic corporations. The same consideration holds for

90. See, e.g., U.S. Convention with the French Republic with Respect to Taxes on Income and Property, July 28, 1967, art. 4, 19 U.S.T. 5280, 5288, T.I.A.S. No. 6518; Organisation for Economic Co-Operation and Devilopment, Model Double Taxation Convention on Income and on Capital art. 5 (1977).

91. European Communities Commission, Proposal For a Council Regulation on the Statute for European Companies, reprinted in BULLIETIN OF THE EUROPEAN CoMMUNITIES 119-21 (Supp. April 1975) ("permanent establishment" concept defines taxing authority over business entities in Member countries); European Communities Commission, Proposed Council Directive on the Common Tax System for Mergers, Split-ups, and Transfers of Assets Involving Companies of Different Member States, reprinted in 1 CoMM. MKT. REP. (CCH) If 3214 (Jan. 15, 1969) (capital gains not taxed if capital assets of acquired establishment not transferred out of acquired's domicile).

92. Such a rule would differ from the "engaged in trade or business within the United States" concept, see p. 1429 \& note 86 supra, and the jurisdictional use of the permanent establishment concept, see note 90 supra. Those concepts provide rules for the assertion of jurisdiction over income by taxing authorities. The rule proposed predicts future tax liability: it indicates the conditions under which the acquisition will not constitute a capital gains recognition event by qualifying as a tax-free reorganization.

93. See Sinrich \& Baller, Payment in Buyer's Stock-Tax-Free Acquisitions of Businesses-The Tax-Free Reorganization, in 1 Business AcQuisitions: Planning ANd Practice. 463, 501 (J. Herz \& C. Baller eds. 1971) (ruling may be initial negotiating goal of acquired).

94. This proposal would replace the $50 \%$-controlling interest limitation of the Guidelines. Rev. Proc. 68-23, 1968-1 C.B. 821, $\$ 3.03(1)$ (d); see notes $25 \& 26$ supra (discussing Guideline requirements).

95. At such a break, the capital gains would be realized and could be recognized. See B. BitTker \& J. Eustice, supra note 86, 14.11 (discussing continuity of interest test).

96. It is questionable whether this is even an "outbound" transfer, see Pugh \& Samuels, supra note 13 , at 276 , although the legislative history indicates that it should be included in that category, see 1976 HOUSE REPORT, supra note 22, at 243. 
straight and reverse subsidiary mergers. ${ }^{97}$ Effective parity requires that the transactions in these cases be exempt from the ruling requirement if they satisfy the establishment rule.

Application of the establishment rule would also remove the need for the toll charge assessed by rulings in direct type-C reorganizations. This toll charge treatment is based on the treatment applied to foreign firms involved in section 351 transfers to controlled corporations. ${ }^{98}$ The tax evasion potential in the type-C situation, however, is reduced, because unlike the section 351 case, the acquired firm does not gain control of the acquirer. ${ }^{99}$ The evasion potential is reduced, in addition, because the transaction is designed to gain control of an ongoing business entity rather than possession of certain assets for a break-up and resale. ${ }^{100}$ When the acquired corporation meets the conditions of the establishment rule, it will remain subject to the United States tax jurisdiction. If direct type-C transactions were exempted from the section 367(a) ruling requirement and the toll charge assessment, effective parity would be achieved.

Discrimination against foreign acquirers under section 368(a)(1)(A) with respect to direct type-A statutory mergers also has no clear policy purpose. ${ }^{101} \mathrm{~A}$ direct merger is similar to a direct type-C purchase of assets in which dissolution of the corporation is an integral step. ${ }^{102}$ The regulations should therefore permit direct type-A mergers to occur if they meet the conditions of the establishment rule.

In sum, the section 367(a) regulations should explicitly exempt from the ruling requirement the classes of transactions that satisfy the establishment rule. ${ }^{103}$ In addition, the section 368 regulations should be modified to permit direct type-A mergers. Adoption of the establishment rule ${ }^{104}$ would satisfy the effective-parity criterion by narrow-

97. See Pugh \& Samuels, supra note 13, at 276.

98. See note 26 supra. A section 351 reorganization involves a transfer of property to a corporation in exchange for stock or securities; after the transfer, the transferor is in control of the transferee. I.R.C. $\$ 351$.

99. See note 26 supra.

100. The guidelines contemplate removal of individual assets from the United States tax jurisdiction. Rev. Proc. 68-23, 1968-I C.B. 821, $\$ 3.02(\mathrm{I})(\mathrm{c})$ (giving examples of trademark expatriation).

101. See note 27 supra. Although individual states often require that merging corporations be incorporated domestically, see id., no policy objective is achieved by federal tax regulations adopting this requirement.

102. The inclusion of both of these types of transactions under the securities regulations, Rule 145, 17 C.F.R. $\$ 230.145$ (1979); see note 10 supra (discussing treatment of assets and merger transactions), is indicative of this similarity.

103. The IRS has the statutory authority to promulgate such a rule. I.R.C. $\S 367$ (a)(2).

104. The IRS has a congressional mandate to provide such an exemption in cases in which it finds that the transactions have no evasion potential. See 1976 HousE REPORT, supra note 22 , at 241 . 
ing the regulatory cost to transactions that actually pose a danger of evasion, and by placing foreign acquirers in a position of effective parity with respect to regulatory costs. Both the standard of regulative neutrality and the tax policy goals of the Internal Revenue Code could thus be satisfied.

\section{B. Amending the Securities Provisions}

The paramount concern in any modification of the securities regulatory framework is maintenance of adequate investor protection. ${ }^{105}$ The subject of foreign securities offerings in the United States has in general been characterized by the tension between this concern and the policy of removing barriers to international capital movements. ${ }^{100}$ Effective parity would require that implementation of regulative neutrality not impair the policy of full and fair disclosure.

The higher regulatory costs of a foreign acquirer result from its relationship to the domestic regulatory framework. ${ }^{107}$ Application of the effective-parity criterion could lead to a different disclosure scheme for foreign acquirers that would bring their regulatory costs closer to those of domestic acquirers. Such a modification could be made without jeopardizing investor protection by implementing the regulatory goal more narrowly and efficiently. The modifications proposed are based upon current SEC policies and rules that distinguish foreign from domestic issuers and that seek to integrate Exchange Act and Securities Act disclosure requirements.

105. See note 32 supra.

106. Cf. Bodolus, The Internationalization of Securities Markets, 29 Bus. LAw. 107, 109-11 (Supp. 1974) (discussing features of European market that conflict with investor protection). For a general discussion of use of United States capital markets by foreign issuers, see I L. Loss, Securities Regulation 363-68 (2d ed. 1961); 4 id. at 2393-98 (Supp. 1969); Stephens, supra note 37. Some commentators have suggested alterations in the regulatory framework in order to facilitate foreign use of the United States securities markets. See, e.g., Bator, supra note 39, at 325 (suggesting "home-to-home" privilege to issuers); Levenson, The Application of United States Securities Laws to Securities Transactions Made in the United States by Canadian Entities, 31 Bus. LAw. 817, 825 (1976) (recommending reciprocal registration with Canadian provinces); Stephens, supra note 37, at 173-78 (discussing various recommendations, including extending Regulation A exemption to subscription rights offerings, providing other investor safeguards besides disclosure, promulgating official guide for accommodations, promulgating exemptions for issuers from specific countries, institutionalizing requests for additional information from foreign issuers now made in SEC comment letter, and expanding Form S-7 for use by foreign issuers).

107. See Stephens, supra note 37, at 150; cf. Exchange Act Rel. No. 16,371, 44 Fed. Reg. 70,132 (1979) (policy of permitting Exchange Act disclosure information to be relied on in lieu of Securities Act disclosure information for certain foreign private issuers); Securities Act Rel. No. 6177, 45 Fed. Reg. 5934 (1980) (proposed Form S-15 furthering integration policy); Mann, New Proposals Will Integrate Securities Disclosure Requirements, Nat'I L.J., Mar. 3, 1980, at 26. 


\section{Current SEC Policy on Foreign Issuers}

Under the Exchange Act, the SEC has adopted a policy of systematic accommodation for foreign issuers. ${ }^{108}$ The SEC recently reaffirmed this policy by adopting a new form, Form 20-F, ${ }^{109}$ that allows foreign issuers to register securities for trading in United States markets under less stringent disclosure requirements than those applicable to domestic issuers. ${ }^{110}$ Foreign issuers are not obligated to file quarterly reports, ${ }^{111}$ and the periodic report form used by foreign issuers ${ }^{112}$ requires much less information than its domestic counterpart. ${ }^{113}$ Another aspect of the accommodation policy is the exemption granted $^{114}$ certain foreign issuers from the proxy disclosure requirements and insider-trading provisions of the Exchange Act. ${ }^{115}$ These provisions indicate that the SEC

108. See Garrett, supra note 42, at D-2 to D-3; Stephens, supra note 36, at 503-10. Pursuant to section $12(\mathrm{~g})(3)$ of the Exchange Act, the SEC grants exemptions from registration to foreign issuers whose securities are traded in the over-the-counter markets. Rule $12 \mathrm{~g} 3-2$, 17 C.F.R. \$ 240.12g3-2 (1979).

109. Exchange Act Rel. No. 16,371, 44 Fed. Reg. 70,132 (1979). Form 20-F is available for foreign issuers that register under sections 12(b), 12(g), or 15(d) of the Exchange Act. Although Form 20-F is more stringent than the forms it replaces, Form 20, 17 C.F.R. $\$ 249.220$ (1979) (Exchange Act foreign issuer registration form), and Form 20.K, 17 C.F.R. $\$ 249.320$ (1979) (Exchange Act foreign issuer annual report form), it is less demanding than the originally proposed Form 20-F, Exchange Act Rel. No. 14,128, 42 Fed. Reg. 58,684 (1977), which would have essentially eradicated the different treatment of foreign issuers. See Stephens, supra note 36, at 519-22 (describing previous reporting regime).

110. Exchange Act Rel. No. 16,371, 44 Fed. Reg. 70,132 (1979). Form 20-F requires less disclosure than its domestic counterpart, Form 10-K, 17 C.F.R. $\$ 249.310$ (1979), in the following areas: general instructions (six-month, rather than four-month, filing period); description of business (less stringent industry segment reporting requirements); control of registrant (reportable ownership percentage $10 \%$ instead of $5 \%$ ); directors and officers (only names and positions, not business experience and general background); management remuneration (only aggregate amount paid); pending legal proceedings (no disclosure of environmental litigation); interest of management in certain transactions (only required when being made public); exhibits (list of parents and subsidiaries required only upon request by SEC); and financial statements (not required to comply with U.S. generally accepted accounting principles or Regulation $S-X$, but must discuss differences in principles used). See Exchange Act Rel. No. 16,371, supra. In addition, the following items of disclosure are not required at all: summary of operations, recent sales of unregistered securities and indebtedness, submission of matters to a vote of security holders, acquisition or disposition of assets, and changes in registrant's certifying accountant. Some of these items were eliminated because they are disclosed elsewhere in the form. Id.

111. 17 C.F.R. $\$ 240.13 a-13(b)(2)(1979)$.

112. Form 6-K, I7 C.F.R. $\$ 249.306$ (1979), as amended by 44 Fed. Reg. 70,132, 70,138 (1979) (requires disclosure only of material made public or available to shareholders).

113. Form 8-K, 17 C.F.R. $\$ 249.308$ (1979); see Stephens, supra note 36, at 522-23 (discussing Form 8-K requirements).

114. Rule 3a12-3, 17 C.F.R. $\$ 240.3 \mathrm{al2}-3$ (1979), as amended by 44 Fed. Reg. 70,132, 70,137 (1979).

115. The exemption applies to issuers that use Form 20-F. Exchange Act $\$ \$ 14(\mathrm{a})$-(c), 16, 15 U.S.C. $\$ \$ 78 n(a)-(c), 78 p$ (1976); see Stephens, supra note 36, at 496. 
has determined that systematic accommodations for foreigners under the Exchange Act do not jeopardize investor protection. ${ }^{116}$

The SEC has also acted under the Securities Act to facilitate use of domestic capital markets by foreign issuers. In this area, however, the SEC has permitted only ad hoc accommodations in the preparation of registration statements by foreigners, ${ }^{117}$ rather than adopting a separate reporting system. Such treatment increases the regulatory costs of the foreign acquirer. ${ }^{118}$ Although the disclosure objectives of both Acts are the same, ${ }^{119}$ their respective treatments of foreign issuers are inconsistent.

In dealing with domestic issuers, the SEC has recently embarked upon a program of integrating the disclosure requirements of the Exchange Act and the Securities Act. ${ }^{120}$ An early application of that policy occurred in the acquisition context. ${ }^{121}$ Securities Act registration under

116. See Exchange Act Rel. No. 16,371, 44 Fed. Reg. 70,132 (1979). But see Stephens, supra note 36, at $519-21$ (expressing concern about adequacy of investor protection).

117. See note 43 supra. Compare Securities Act Rel. No. 5893, 42 Fed. Reg. 65,554 (1977) (no industry-segment reporting exemption for foreign issuers) with Exchange Act Rel. No. 16,371, 44 Fed. Reg. 70,132 (1979) (modifying industry-segment reporting requirement in adoption of Form 20-F).

118. See pp. 1420-21 supra.

119. Advisory Committee on Corporate Disclosure, Report to the Securities and Exchange Commission, 95th Cong., Ist Sess. 347 (Comm. Print No. 29, 1977) [hereinafter cited as Advisory Commitre ReporT]; see Letter from President Roosevelt to Congress (Feb. 9, 1934), reprinted in S. REP. No. 792, 73d Cong., 2d Sess. 1-2 (1934) (Exchange Act second step to Securities Act in broad purpose of protecting investors); Anderson, The Disclosure Process in Federal Securities Regulation: A Brief Review, 25 Hastings L.J. 311,329 (1974) (two basic purposes served by disclosure requirements of both acts). The Advisory Committee recommended adoption of a coordinated disclosure form, Form CD, to replace all registration and reporting forms under both Acts. Advisory CoMmitreE REPORT, supra, at 428 .

120. The 1969 Wheat Report recommended administrative measures to integrate the disclosure systems under the Securities Act and the Exchange Act. Securiries and ExChange Commission, Disclosure to Investors (1969). As a result of this report, the SEC made several changes: it expanded the availability of the shortened registration form, Form S-7; it adopted the short form for the registration of secondary offerings and subscription or conversion offerings, Form S-16; and it adopted Rule 145, which provides for the registration of acquisition offerings on Form S-14. These forms depend in part upon prior compliance with Exchange Act disclosure requirements (Forms S-7 and S-16) or on the use of Exchange Act type disclosures (Form S-14, see note 10 supra).

The 1977 Report of the SEC's Advisory Committee on Corporate Disclosure recommended to the SEC a complete integration of the disclosure systems under the Acts. Advisory Commitee RePort, supra note 119, at 425. The SEC has continued to pursue this policy.

121. The SEC apparently considers this context an appropriate one for application of the integration policy. In addition to the promulgation of Rule 145, the SEC has recently proposed Form S-15. Securities Act Rel. No. 6177, 45 Fed. Reg. 5934 (1980). This new form would be available for exchange offers, see note 9 supra, as well as for mergers and asset purchases under Rule 145. Eligibility for use of the shortened form would be determined by eligibility for Form S.7-primarily, United States incorporation and previous compliance with Exchange Act disclosure requirements. 
Rule $145^{122}$ of securities used in acquisitions is similar to the proxy disclosure requirements of the Exchange Act. ${ }^{123}$ The financial statements required by the Rule 145 registration form ${ }^{124}$ generally must conform to those required by Form 10,125 the general Exchange Act registration form for domestic issuers. ${ }^{126}$ Full Form S-1 registration, otherwise required under the Securities Act, is not necessary in these acquisition situations. This integration policy should be followed when considering the SEC's treatment of foreign acquirers.

The SEC has recently begun to take certain actions more consistent with the Exchange Act treatment of foreign issuers. The Commission has provided systematic accommodations to foreign issuers in the registration of subscription offerings. ${ }^{127}$ These accommodations indicate that international capital movements can be facilitated without compromising the full-and-fair disclosure policy of the Securities Act. ${ }^{128}$ In accordance with the SEC's integration policy, the systematic accommodations for foreign issuers under the Exchange Act should be extended to acquisition registrations of foreign acquirers.

\section{Alternative Modifications}

The criterion of effective parity suggests two possible modifications of the securities regulatory framework. ${ }^{129}$ Both attempt to narrow the

122. 17 C.F.R. $\$ 230.145$ (1979).

123. See note 10 supra.

124. Form S-14, 17 C.F.R. \$ 239.23 (1979).

125. 17 C.F.R. $\$ 249.210$ (1979).

126. Schneider \& Manko, Rule 145, 5 REv. SEc. REg. 811,820 (1972).

127. Securities Act Rel. No. 6156, 44 Fed. Reg. 70,131 (1979). Foreign issuers will be permitted to register pro rata rights offerings on the shorter Form S-16 without satisfying certain eligibility criteria.

Form S-16 requires substantially less disclosure than Form S-1 or S-7, on which a foreign jssuer would normally have to register a subscription offering. C $f$. Williams, Trading in the United States in Foreign Securities and Securities Distributed Outside the United States Without Registration under the Securities Act of 1933, in Sixth ANNuAL Instirute on Securities Regulation 327, 335-40 (1975) (discussing problems of rights offerings prior to Securities Act Rel. No. 6156). Domestic issuers must satisfy Form S-7 eligibility requirements, but foreign issuers will be exempted from some of these. Securities Act Rel. No. 6156, 44 Fed. Reg. 70,131 (1979) (in place of Form S-7 eligibility requirements, must furnish English translation of annual report or latest Form 20-F).

Another recent accommodation to foreign issuers was made in the area of disclosure of management remuneration. Securities Act Rel. No. 6157, 44 Fed. Reg. 70,130 (1979) (aggregate group disclosure only).

128. Securities Act Rel. No. 6156, 44 Fed. Reg. 70,131 (1979); Securities Act Rel. No. 6157, 44 Fed. Reg. 70,130 (1979). Former SEC Chairman Garrett, in 1974, left open the possibility of systematic accommodation under the Securities Act. See Garrett, supra note 42 , at D-1 ("When the same problem tends to become a regular and general matter, then we must think further and more broadly and consider adopting rules and forms.")

129. See note 106 supra (discussing commentators' recommendations for alterations to accommodate foreign issuers). 
securities regulations in the foreign-securities acquisition context in order to reduce the conflict between the policies of investor protection and unimpeded capital movements.

The first modification involves extension of the disclosure philosophy of Rule 145. Foreign acquirers should be permitted to route the Securities Act registration of their acquisition securities through the Exchange Act disclosure structure. ${ }^{130}$ This could be accomplished by allowing the use of the foreign issuer equivalent to the Exchange Act registration form, Form 20-F, or some analogue. ${ }^{131}$ Once registered, the securities would be subject to the current foreign-issuer disclosure regime of the Exchange Act.

The alternative modification would be to design a Securities Act registration form specifically for foreign acquirers. ${ }^{132}$ Such a form would make systematic ${ }^{133}$ the accommodations currently granted to foreign issuers on an ad hoc basis. In addition, specific changes in the extent of disclosure could be made. Guides to a new form or different forms could be tailored to the accounting and business practices of various home countries of acquirers. ${ }^{134}$ The necessary accommodations would vary with each country's regulatory framework. ${ }^{135}$

In addition to implementing regulative neutrality, these modifica-

130. Under Rule 145, domestic acquirers are already permitted to route their Securities Act disclosure through section $14 \mathrm{~A}$ proxy requirements and Form 10. See pp. 1434-35 supra.

131. An analogue could be a new Securities Act form or some modification of Form S.14, which incorporates the Exchange Act reporting structure for foreign issuers. In 1972, the SEC did consider formal exemptions for foreign acquirers when it promulgated Rule 145. See Securities Act Rel. No. 5316, 37 Fed. Reg. 23,631 (1972). The SEC rejected such exemptions as inconsistent with investor protection under the Securities Act. The 1972 position of the SEC should be abandoned, in light of the promulgation of Form 20-F, the adoption of certain systematic accommodations under the Securities Act, the SEC's policy of integrating Securities Act and Exchange Act disclosure requirements, and international capital movement policy considerations.

132. This would amount to a modified double-standard for foreign acquirers. See Brownell, Cohen, Heller, Loss, \& Stevenson, Legal Problems of Issuing and Marketing Foreign Securities in the United States, in International Financing and Investment 430, 456-57 (J. McDaniels ed. 1964); Cohen \&: Throop, Investment of Private Capital in Foreign Securities, in A Lawyer's Guide to International Business Transactions 519, 566 (W. Surrey \& C. Shaw eds. 1963) (not providing separate disclosure scheme runs counter to U.S. policy).

133. Several commentators have called for a more systematic method of accommodation. See, e.g., Stephens, supra note 37, at 175-76 (promulgate guides); cf. Garrett, supra note 42 , at D-1 (some form of systematization might be required in future).

134. See Stephens, supra note 37 , at 175-77. Because a limited number of countries produce the vast majority of foreign acquirers, see note 2 supra, this suggestion would not be unwieldy to implement. It would, however, result in greater expense to the SEC in preparing individual forms or guides. On the other hand, the regulatory compliance costs to the foreign acquirer would decrease. See note 82 supra.

135. For example, the form for British and Japanese acquirers would require few changes in the acquirer's financial statements. Stephens, supra note 37 , at 158.59. 


\section{Foreign Acquisitions}

tions might also be the most appropriate way of encouraging higher international disclosure standards. ${ }^{136}$ The proposals balance the competing policy approaches of holding the foreign acquirer to strict American requirements ${ }^{137}$ and giving it a blanket exemption. ${ }^{138}$ Either proposal would enable foreign acquirers to enter the United States securities market and then to adjust gradually to the domestic level of disclosure.

\section{Conclusion}

The modifications in the tax and securities regulatory framework proposed in this Note would increase the feasibility of securities acquisitions for foreign acquirers. By approaching effective parity in the structuring decision of foreign acquirers, United States policy on capital movements could be furthered without sacrificing the goals of preventing tax evasion and protecting investors. Regulations consistent with this policy would contribute to the orderly development and expansion of an international securities market.

136. See Bodolus, supra note 106, at 111-12 (discussing role of SEC accommodations in raising international disclosure standards).

137. See Stephens, supra note 37, at 164-69; cf. Exchange Act Rel. No. 14,128, 42 Fed. Reg. 58,684 (1977) (original Form 20-F proposal holding foreign issuers to domestic disclosure standards).

138. Bator, supra note 39 , at 325 (reciprocal registration with foreign countries); cf. Levenson, supra note 106, at 825 (recommending reciprocal registration with Canadian provinces). 